Maurer School of Law: Indiana University

Digital Repository @ Maurer Law

1969

\title{
The New Administrative State: Judicial Sanction for Agency Self- Determination in the Regulation of Industry
}

Ralph F. Fuchs

Indiana University School of Law

Follow this and additional works at: https://www.repository.law.indiana.edu/facpub

Part of the Administrative Law Commons, Courts Commons, and the Public Policy Commons

\section{Recommended Citation}

Fuchs, Ralph F., "The New Administrative State: Judicial Sanction for Agency Self-Determination in the Regulation of Industry" (1969). Articles by Maurer Faculty. 1651.

https://www.repository.law.indiana.edu/facpub/1651

This Article is brought to you for free and open access by the Faculty Scholarship at Digital Repository @ Maurer Law. It has been accepted for inclusion in Articles by Maurer Faculty by an authorized administrator of Digital Repository @ Maurer Law. For more information, please contact rvaughan@indiana.edu. 


\section{THE NEW ADMINISTRATIVE STATE: JUDICIAL SANCTION FOR AGENCY SELF-DETERMINATION IN THE REGULATION OF INDUSTRY}

\section{RALPH F. FUCHS* \\ I. The New Charter}

Two decisions of the United States Supreme Court in the 1967-68 Term, enlarging a trend which has been developing for some time, create a new basis for expanding the methods by which federal regulatory agencies may meet new problems. This foundation for extending authority and adapting administrative processes to new uses involves a major realignment of judicial, agency, and legislative authority. It sanctions not merely the extension of existing rules and methods to related areas, but also significant procedural innovations. The agency operations which result, although they continue to have a statutory basis, may range considerably beyond those which the mandate of existing legislation can accommodate comfortably.

The two decisions are those in the Permian Basin Area Rate Cases, ${ }^{1}$ sustaining Federal Power Commission orders which regulate the prices and price practices of many independent natural gas producers and United States v. Southwestern Cable Co., ${ }^{2}$ involving the Federal Communications Commission's regulation of CATV systems. The Permian Basin decision builds on Phillips Petroleum Co. v. Wisconsin ${ }^{3}$ and a line of intervening decisions; Southwestern Cable draws on Permian Basin for part of its rationale. Both decisions derive additional support from recent decisions sustaining the expanded use of agency rule-making instead of adjudication in the interest of effective enforcement ; $;$ but they increase the variety and scope of permissible innovation.

\section{The Instant Cases}

In the Phillips Petroleum decision of $1954^{5}$ the Supreme Court imposed on a reluctant Federal Power Commission the task of regulating sales of natural gas in interstate commerce by independent producers. It construed the Natural Gas Act to cover these sales, although the dominant construction of the statute, to which the Commission had adhered, was that they were not included. The opinion of the 5-3 majority of the Court relied primarily

* University Professor of Law, Indiana University.

1. 390 U.S. 747 (1968).

2. 392 U.S. 157 (1968).

3. 347 U.S. 672 (1954).

4. Shapiro, The Choice of Rulemaking or Adjudication in the Development of Administrative Policy, 78 Harv. L. REv. 921 (1965); Fuchs, Agency Development of Policy Through Rule-Making, 59 Nw. U.L. REv. 781 (1965).

5. 347 U.S. 672 (1954). 
upon the literal meaning of certain words of the Act; but the more significant reason for the decision, it seems fair to say, was the consumer or "public" interest in reasonable natural gas prices which underlay the statute. Absent regulation, increasing demand might have continuously driven up prices beyond the point needed to sustain successful discovery, production, and gathering of the gas. The Court has alluded to these considerations in later opinions. ${ }^{6}$

When the Commission turned to carrying out the Court's mandate, it made resourceful use of the rule-making, licensing and rate-fixing powers which the Natural Gas Act conferred for the regulation of a relatively small number of pipelines, laboring "with obvious difficulty to regulate a diverse and growing industry under the terms of an ill-suited statute." Especially important among the powers employed were the authority to attach conditions to certificates of convenience and necessity for new production, ${ }^{8}$ the power "to prescribe ... such ... regulations as it [the Commission] may find necessary or appropriate to carry out the provisions" of the statute, ${ }^{9}$ and the authority to combine several rate- or price-fixing proceedings into one group proceeding. Other agencies had developed this group procedure which presumably was available to the Commission in connection with its obligation to determine just and reasonable rates. ${ }^{10}$

Significant use of these powers in connection with the issuance of certificates followed the Supreme Court's decision in the Atlantic Refining case. ${ }^{11}$ This decision declared it to be the Federal Power Commission's duty to consider limiting the initial prices at which gas might be sold until just and reasonable rates might be determined in later proceedings. The Commission carried out this mandate in several ways. (1) It adopted a regulation, based on a rule-making proceeding in accordance with Section 4 of the Administrative Procedure Act, ${ }^{12}$ which proscribed certain kinds of price-increase or escalation clauses in contracts between producers and purchasers of gas. Applications accompanied by contracts which contained such clauses would not be considered. ${ }^{13}$ (2) It issued a Statement of General Policy, ${ }^{14}$ without prior proceedings, which established interim maximum prices to be charged in the several producing areas of the country. These prices could be authorized under

6. In Atlantic Ref. Co. v. Public Service Comm'n, 360 U.S. 378 (1959), which held that price ceilings should be imposed on new production, the Court emphasized the legislative purpose "to afford consumers a complete, permanent and effective bond of protection from excessive rates and charges," 360 U.S. at 388, and the need to prevent "a triggering of general price rises," id. at 391.

7. Permian Basin Area Rate Cases, 390 U.S. 747, 756 (1968).

8. Natural Gas Act $\$ 6(\mathrm{e}), 15$ U.S.C. $\$ 717 \mathrm{f}(\mathrm{e})$ (1964).

9. 15 U.S.C. \& 717 o (1964)?

10. 15 U.S.C. \& $717 \mathrm{c}$ (1964). The dissenting opinion of Mr. Justice Douglas in the Permian Basin Cases refers to certain earlier instances of the use of the group technique. 390 U.S. at $831-32$.

11. Atlantic Ref. Co. v. Public Service Comm'n, 360 U.S. 378 (1959).

12. 5 U.S.C. $\$ 553$ (Supp. III 1968).

13. 18 C.F.R. \$ 154.93 (1968). See FPC v. Texaco, Inc., 377 U.S. 33 (1964).

14. 18 C.F.R. $\$ 2.56$ (1968). 
temporary certificates which new producers might accept pending consideration of their applications for permanent certificates. ${ }^{15}$ (3) The Commission foreclosed statutory rate-increase filings for sales authorized by these certificates so long as they remained in effect. ${ }^{16}$ (4) It conditioned permanent certificates upon the observance of maximum prices set by the Commission, ${ }^{17}$ subject to moratoria or restrictions on rate-increase filings, until specified dates or the earlier determination of just and reasonable rates. ${ }^{18}$ (5) It decided to combine the rate determinations incident to geographically related certificate filings, so as to permit a single determination to be made for a group of producers or a producing field, ${ }^{19}$ and ( 6 ) provided that these prices would be determined on the basis of prices previousiy in effect and on related market factors, instead of on producers' costs and needs. ${ }^{20}$

Producers subject to the price limitations that were effectuated by these expedients could not withdraw from their commitments to sell gas upon the prescribed terms once they had made the choice of accepting temporary or permanent certificates. ${ }^{21}$ Certain procedures set forth in the statute or traditionally followed for the certification and regulation of gas sales became inoperative. These were (1) an adjudicatory hearing upon an application for a certificate, when the certificate was accompanied by a proposal for a proscribed price-increase clause $; 22$ (2) opportunity for a seller to file a price increase permitted by his contract with a buyer or buyers, subject to the Commission's suspension, hearing, and refund procedures, when a price ceiling or moratorium on price increases applied $;^{23}$ and (3) evidence and decision on the authorization of new prices, focusing on the individual producing enterprise. $^{24}$

Since the measures adopted by the Commission, except the proscription

15. See 15 U.S.C. \& $717 \mathrm{f}$ (c) (1964). The producer's option of rejecting a temporary certificate and awaiting a decision on a permanent one led the Federal Power Commission in amending the Statement in 1965 to describe it as one not imposing a course of conduct on anyone, but as merely setting forth the Commission's own "contemplated course of action" for the guidance of its staff and the public. 30 Fed. Reg. 4671 (1965).

16. Sections 4(d) and (e) of the Natural Gas Act authorize any natural gas company transporting or selling natural gas in interstate commerce to file new rates with the Federal Power Commission. These take effect in 30 days unless suspended by the Commission for not more than 5 months in addition. If the new rates are not acted upon by the Commission within that time, they may then take effect, subject to possible refunds to the extent they are later found to be too high. 15 U.S.C. $\$ \$ 717 f(d)$, (e) (1964). As to the Commission's authority to suspend the privilege to make such filings under temporary certificates, see FPC v. Hunt, 376 U.S. 515 (1964).

17. See United Gas Improvement Co. v. Callery Properties, Inc., 382 U.S. 223 (1965).

18. Id.; Permian Basin Area Rate Cases, 390 U.S. 747, 780 (1968).

19. See FPC v. Sunray DX Oil Co., 391 U.S. 9, 26-36 (1968); United Gas Improvement Co. v. Callery Properties, Inc., 382 U.S. 223, 226 (1965). (1965).

20. See United Gas Improvement Co. v. Callery Properties, Inc., 382 U.S. 223, 226-28

21. See FPC v. Sunray DX Oil Co., 391 U.S. 9, $44-47$ (1968).

22. See FPC v. Texaco, Inc., 377 U.S. 33 (1964).

23. See note 16 supra. (1965).

24. See United Gas Improvement Co. v. Callery Properties, Inc., 382 U.S. 223, 226-28 
of price escalation clauses, were temporary, applicable only until more permanent terms to govern certification and prices could be promulgated, this suspension of statutory procedures seemed less serious than it might have if permanent departures from the statutory processes had been contemplated. However, because of delay in the establishment of more permanent controls, these temporary measures have regulated the industry for many years, on a scale which has been graphically portrayed. ${ }^{25}$ Rightly or wrongly, judicial extension of the Natural Gas Act by the Phillips decision has led to the development by the Commission and the courts of complicated measures of control in which the legislature has played no active part. ${ }^{26}$ Although producers could have avoided these measures by refraining from sales of gas in interstate commerce until more permanent controls were established, such an option is often economically unrealistic, and the historical development of the control measures has been such that much production has been irrevocably committed before the full development has occurred or become known. ${ }^{27}$

As these regulatory measures were being developed, the Federal Power Commission inaugurated its area rate proceedings, aimed at the determination of reasonable rates for substantially all of the independent producers ${ }^{28}$ in each of the major natural gas producing areas of the country. The Permian Basin proceeding, the first begun and for three years the only one concluded, was launched on December 23,1960, to cover an area defined in the initiating order. ${ }^{20}$ Rate proceedings involving a large number of established producers and a limited number of applications for certificates were consolidated in it, and a substantial number of intervenors who possessed a requisite interest in the outcome, including states and state agencies, municipalities, and trade groups, were admitted. ${ }^{30}$ The proceeding lasted more than four and one-half years, including two years of hearings, and produced more than 30,000 pages (1964).

25. Brown, J., in Hunt v. FPC, 306 F.2d 334, 343 (5th Cir. 1962), rev'd, 376 U.S. 515

26. Two bills to change the situation created by the Phillips decision were stopped only by presidential veto. See notes 147-54 infra and accompanying text. For illuminating accounts of these developments and of the emergence of many of the problems discussed infra see Johnson, Producer Rate Regulation in Natural Gas Certification Proceedings: CATCO in Context, 62 Colvum. L. Rev. 773 (1962); Ross, The Area Rate Proceedings: An Unsettled Experiment in Public Control of Natural Gas Prices, 18 Sw. L.J. 165 (1964); Scott, Federal Certificate Regulation of Producer Gas Sales: Initial Rates and Related Problents, 18 Sw. L.J. 570, 682-93 (1964); Note, The FPC and Indefinite Price Escalation Clanses: Remedy for Administrative Breakdown, 73 YALE I.J. 1283 (1964).

27. Some production was committed under temporary certificates without knowledge that price increases during the continuance of these certificates might be barred. See Hunt v. FPC, 306 F.2d 334, 336-38 (5th Cir. 1962), rev'd, 376 U.S. 515 (1964). It apparently was not known until the decision in Public Service Comm'n v. FPC, 329 F.2d 242, 248-50 (1964), that prices charged under temporary certificates which made no provision for refunds might turn out to have been accompanied by a refund obligation. FPC v. Sunray DX Oil Co., 391 U.S. 9, 40-45 (1968).

28. An independent producer is one that is not part of a regulated pipeline enterprise.

29. 24 F.P.C. 1121 (1960).

30. Area Rate Proceeding, 34 F.P.C. 159, 171, 407-17 (1965). The total number of parties was 384 , including 336 producers and applicants for certificates. 
of transcript. ${ }^{31}$ At its conclusion the Commission issued orders which (1) established reasonable maximum rates within the area, varying somewhat geographically and differentiating between gas-well gas committed to interstate sale on or after January 1, 1961, and gas-well gas committed before that date together with all gas produced in conjunction with oil; (2) provided adjustments for quality of gas; (3) required refunds under Section 4(e) of the Act from producers whose challenged rate increases had been found to be excessive; (4) established a moratorium on rate increases until January 1, 1968; (5) extended the proscription of certain rate-increase clauses, which applied to contracts after its date, ${ }^{32}$ to prevent increases under earlier contracts beyond the rates permitted in the order; $; 3$ (6) granted certificates to the applicants who were parties to the proceeding, conditioned as to rates and rate increases in conformity to the principal order $; 34(7)$ issued an order to show cause why the same rates should not be prescribed for existing production and production covered by pending applications of producers not previously party to the proceeding $;^{35}$ (8) exempted small producers, defined as those whose national production is less than ten billion cubic feet of gas a year, from downward quality adjustments of their prices for refund purposes, and initiated rulemaking procedures to exempt them from certain application, price-filing, and reporting requirements of the Act and regulations ; ${ }^{36}$ and (9) preserved opportunity for individual respondents to seek exemption from the moratorium on price increases and from other restrictions imposed by the orders. ${ }^{37}$

The Permian Basin orders and the Supreme Court decision confirming them add to the previous extra-statutory aspects of independent gas producer regulation in two important ways which possess enhanced significance because they affect permanent rate determinations and not merely interim restrictions. They are (1) the moratorium which temporarily withdrew, except in instances of special justification, the privilege of securing Commission consideration of rate increases under Section 4(e) of the Act, and (2) the use of average cost figures in establishing uniform rates for many producers at one time, subject to possible individual relief upon petition. The determination of individual exemptions upon petition might consume long periods of time. Interim relief (such as Section 4(e) provides by permitting increased rates to be collected, subject to possible refunds, after six months from their communication to the Commission) would not be available. Hence the moratorium, like the original

31. Permian Basin Area Rate Cases, 390 U.S. 747, 755 n.4 (1968).

32. See text accompanying note 13 supra.

33. Principal order, 34 F.P.C. 239-43 (1965).

34. Order Issuing Certificates, 34 F.P.C. 418-24 (1965).

35. Order to Show Cause, 34 F.P.C. 424-34 (1968).

36. 34 F.P.C. at 234-36, 241 ก (F) (3) ; id. at 434-37 (1968). On a national basis only about 75 major companies would not be small producers and would remain subject to the Federal Power Commission's full requirements under the Natural Gas Act. Id. at 235.

37. 34 F.P.C. at $242 \pi(\mathrm{H}), 243$ 丹ा (K), (L), 423 đ(K). 
regulation proscribing without hearings on certificate àpplications certain rateincrease clauses, withholds particular procedures seemingly secured by the statute. The average-cost basis of rate determination departs in a fundamental way from the previous common understanding of legal requirements in the fixation of "just and reasonable" rates, as Mr. Justice Douglas stressed in his Permian Basin dissent. ${ }^{38}$ The legislature, again, has not played an affirmative role in fashioning these significant new processes.

In the Southwestern Cable ${ }^{39}$ case the order which the Supreme Court sustained resulted from the Federal Communications Commission's initiative in meeting new needs created by advancing technology. The Communications Act, administered by the Commission, confers specific powers to regulate common carriers of communications on the one hand $\mathrm{d}^{40}$ and the transmission of energy, communications, and signals by radio, including broadcasting, on the other. ${ }^{41}$ Community antenna television systems began in 1950. They disseminate a variety of selected television programs by wire, within limited geographical areas, to paying subscribers. The television picture which results from these methods is of superior quality. The systems obtain some of their programs from the broadcasts of distant stations, and transmit them or arrange to have them transmitted by microwave or wire to the localities where they are distributed. The CATV systems neither hold themselves out as common carriers nor engage in radio transmission, except where they supply microwave transmissions to their own systems. Nevertheless, the entire scheme of broadcast regulation conferring exclusive local use of designated radio frequencies on enterprises licensed by the Commission, ${ }^{42}$ is economically dislocated by competition from program services which do not depend on similar authorization. One of the Commission's statutory goals in apportioning scarce broadcasting frequencies has been to maintain economically viable enterprises, able and willing to render adequate, locally oriented public service. ${ }^{43}$

The Commission commenced to regulate CATV under the existing statute after Congress failed to respond to proposals for new legislation. ${ }^{44}$ In 1965 , under its general rule-making power, ${ }^{45}$ it adopted regulations for CATV em-

38. 390 U.S. at 829 .

39. United States v. Southwestern Cable Co., 392 U.S. 157 (1968).

40. These are contained in Title II of the Act, 47 U.S.C. \& 201 et seq. (1964).

41. Title III of the Act, 47 U.S.C. \& 301 et seq. (1964).

42. The statute directs that in allocating radio frequencies and administering the standard of public convenience and necessity, which governs the granting of licenses, the Commission shall seek to "provide a fair, efficient, and equitable distribution of radio service" to each state and community, and may require information from broadcasting license applicants as to their character and financial, technical, and other qualifications to operate stations. 47 U.S.C. $\$ \S 307$ (a), (b), 308(b) (1964).

43. W. K. Jones, Licensing of Major Broadcast Facilities by the Federat. Communicatrons Commissron (Report to the Administrative Conference of the United States, 1962), 43-44, 51-64; Rules re Microwave-Served CATV, 38 F.C.C. 683, 698-701 (1965).

44. The Supreme Court's opinion in the Southwestern Cable case summarizes the development of CATV regulation. 392 U.S. 157, 164-67 (1968).

45. 47 U.S.C. \$\$ 154(i), 303 (f), (r) (1964). 
ploying microwave. ${ }^{46}$ These were modified and supplemented in $1966^{17}$ to provide more complete regulation for both microwave and wire CATV. The resulting rules ${ }^{48}$ require community antenna television systems to make arailable to their subscribers the programs of local broadcasters ${ }^{49}$ and upon request to display the same programs from other locations only after a one-day delay..$^{50}$ The regulations also provide that in the 100 largest television markets of the country the CATV systems may not import programs from outside, in the absence of certain "grandfather" rights, unless the Commission, after "a full evidentiary hearing," authorizes this service as "consistent with the public interest ... particularly the establishment and healthy maintenance of television broadcast service in the area." 51 The regulations also authorize applications to be made for "separate or additional relief" in relation to CATV matters, and provide variable procedures by which the Commission will entertain and dispose of such applications. These procedures involve informal written applications and responses, followed when necessary by such "other procedures, such as oral argument, evidentiary hearing, or further written submissions," as the Commission may deem appropriate. ${ }^{\text {.2 }}$

The authority for these regulations and the validity of a Commission order implementing them were examined by the Supreme Court as a result of a San Diego television broadcaster's request for relief from CATV operations of the Southwestern Cable Company, which transmitted programs originating in Los Angeles to subscribers in San Diego. The Commission, pending hearings which it initiated, restricted somewhat Southern's CATV service by means of an interim order. In respondent's proceeding for review, the Supreme Court sustained this interim order and the Commission's authority to regulate CATV. It dealt of necessity with the nature of the regulations but did not pass directly on their validity. ${ }^{53}$ However, particular provisions have been sustained by courts of appeals. ${ }^{54}$

The Court, in part, found authority in Section 2(a) of the Act ${ }^{55}$ for the

46. 30 Fed. Reg. 6060-63, 13370-75 (1965). These regulations operated by attaching conditions to the Commission's authorization of the transmissions, limiting the use that might be made of microwave signals by CATV systems receiving them.

47. 31 Fed. Reg. 4568-73 (1966).

48. 47 C.F.R. \$\$ 21.710-21.714 (common-carrier microwave service to CATV systems) ; 74.1001-74.1083 (CATV-owned microwave transmission); 74.1101-74.1109 (operation of CATV systems); $91.557-91.561$ (independent microwave service to CATV systems) (1968).

49. Id. §§ $21.712,74.1033,74.1103,91.559$.

50. $I d$.

51. Id. §§ 74.1105-74.1107.

52. Id. \& 74.1109. Applications may be by interested persons, such as CATV or microwave operators seeking waivers of rules and broadcasters or others seeking additional action or the resolution of disputes.

53. United States v. Southwestern Cable Co., 392 U.S. 157, 167 (1968).

54. Black Hills Video Corp. v. FCC, 399 F.2d 65 (8th Cir. 1968); Conley Electronics Corp. v. FCC, 394 F.2d 620 (10th Cir. 1968) ; Wheeling Antenna Co. v. United States, 391 F.2d 179 (4th Cir. 1968) ; Hubbard Broadcasting, Inc. v. FCC, 385 F.2d 979 (D.C. Cir. 1967); Channel 9 Syracuse, Inc. v. FCC, 385 F.2d 969 (D.C. Cir. 1967).

55. 47 U.S.C. \& $152(\mathrm{a})(1964)$. 
regulations the Commission had adopted and for the order restricting the respondent. This introductory Section states that

[t]he provisions of this Act shall apply to all interstate and foreign communication by wire or radio and all interstate and foreign transmission of energy by radio, which originates and/or is received within the United States, and to all persons engaged within the United States in such communication or such transmission of energy by radio, and to the licensing and regulating of all radio stations as hereinafter provided....

Community antenna television systems conduct "interstate . . communication by wire or radio." By its terms, the quoted provision extends the authority of the Commission as it is spelled out elsewhere in the Act to CATV systems. The Court, however, speaks of the section as extending the "regulatory authority" of the Commission, apparently in the sense of a broad power to achieve the purposes of the statute. ${ }^{56}$

The Commission has the statutory power, contained in Title III of the Act, relating to radio, to issue "such rules and regulations and prescribe such restrictions and conditions, not inconsistent with law, as may be necessary to carry out the provisions of this chapter ...."57 It also has the power, contained in the general Title, to "perform any and all acts, make such rules and regulations, and issue such orders, not inconsistent with this chapter, as may be necessary in the execution" of the functions of the Commission. ${ }^{58}$ The Commission's order against the Southwestern Cable Company came within the second of these two powers if it can be construed as a grant of authority which embraces a "function," bestowed by Section 2(a), of regulating "all forms of communication by wire or radio." The regulations authorizing the proceeding that led to the order came within both powers if the former embraces wire in addition to radio communication, as literally it does, and if Section $2(a)$ is a "provision" which authorizes the regulation of CATV.

By construing these three sections of the statute broadly in relation to each other, ${ }^{59}$ the Court established a scope of agency authority significantly greater than the terms of each provision appear to bestow. Section 2(a), broad as to subject matter, depends by its terms on other provisions of the Act. The other two provisions, which authorize a broad range of implementing mea-

56. United States v. Southwestern Cable Co., 392 U.S. 157, 172-73 (1968).

57. 47 U.S.C. $\$ 303(\mathrm{r})$ (1964). See 392 U.S. at 178. The same section of the Act as originally enacted in 1934 contains another paragraph to the same effect, from which the Court cites only the qualified authority it bestows to adopt regulations to prevent interference among broadcasting stations. 392 U.S. at 174. See 47 U.S.C. \& 303(f), (h) (1964). The Commission itself cited \$ 303 as a whole in support of its authority to adopt the CATV regulations. Rules re Microwave-served CATV, 38 F.C.C. 683, 741 (1965); CATV Second Report and Order, 2 F.C.C. 2d 725, 788 (1966), but stressed $\S 303$ ( $\mathrm{r}$ ) in its 1966 statement just cited. See also Appendix C to CATV Second Report and Order, (Commission's Memorandum on Its Jurisdiction and Authority), 2 F.C.C.2d 793, 794.

58. 47 U.S.C. § $154(\mathrm{i})$ (1964).

59. 392 U.S. at $167-69,171-75,177-78,180-81$. 
sures, are to aid in carrying out the powers conferred elsewhere in the statute. The result of combining them is that the Commission is authorized, when necessary to carry out its total mission as visualized by it and by the courts, to adopt a wide variety of means to regulate unspecified aspects of communications, in contrast to the defined means which the statute provides for regulating specified portions of the communications industry. ${ }^{.0}$

The opinion of the Court stresses that "[n]othing in the language of [Section 2(a)], in the surrounding language, or in the Act's history or purposes limits the Commission's authority to those activities and forms of communications that are specifically described by the Act's other provisions," ${ }^{\circ 1}$ and that the Commission has "'a comprehensive mandate'," with " 'not niggardly but expansive powers'," 62 to carry out its task. The Court also repeats its pronouncement in the Permian Basin case that "we may not, "in the absence of compelling evidence that such was Congress' intention ... prohibit administrative action imperative for the achievement of an agency's ultimate purposes." "There is," it holds, "no such evidence here . . .." ${ }^{33}$ This view of agency powers typically sanctions new methods authorized only generally by statute of dealing effectively with activities within the scope of agency authority; here, the Court's sweeping interpretation of Section 2(a) justifies innovative methods for regulating new segments of an industry, such as CATV, which, although not specified in the statute, are thought to fall within its purpose.

\section{Breadth of the Charter}

Despite the breadth of the foregoing view of the Court, the principle of semi-autonomous, expandible agency authority is not without limits. The extension of Federal Power Commission authority to independent natural gas producers embraced transactions which were closely related in an economic sense to the regulatory task previously assigned by Congress. In the Southwestern Cable opinion the Court took occasion "to emphasize that the authority which we recognize today . . . is restricted to that reasonably ancilliary to the effective performance of the Commission's various responsibilities for the regulation of television broadcasting." 64 The Court expressed "no views as to the Commission's authority, if any, to regulate CATV under any other cir-

60. Title II of the Communications Act, relating to carriers, bestows the usual range of authority over public utilities with respect to entry, rates, services, accounts, and mergers. Title III relating to radio relates mainly to allocation of use of the spectrum, licensing, enforcement of certain requirements for broadcasters, and administration of technical standards.

61. 392 U.S. at 172 (1968). (1943).

62. Id. at 173, citing National Broadcasting Co. v. United States, 319 U.S. 190, 219

63. 392 U.S. at 177-78, citing 390 U.S. at 780.

64. Id. at 178. 
cumstances or for any other purposes."65 Ancillarity may be broadly or narrowly construed according to a practical judgment of need in the performance of an agency's principal tasks and a sense of the relative importance of countervailing considerations. Although the language of the Communications Act on which the Court relied does not expressly restrict the scope of the Commission's function in relation to wire and radio communication and radio transmission, appropriate limits are implicit in the nature of the task to.be performed. Attempts to regulate private communication by private wire, having no impact on common carriers, might not be acceptable.

Procedurally, the measures devised by an agency and sanctioned by the courts must obviously conform to the requirements of due process of law. The Court suggested a further possible limitation where an attempt is made to supplant a statutory proceeding for the performance of an established function. Answering an objection that the order against the Southwestern Cable Company was based on freer procedures than the statute authorizes for those cease and desist orders which it specifically sanctions, ${ }^{66}$ the court was willing to "assume that" statutory cease and desist orders against violators of the Act "are proper only after hearing or waiver of the right to hearing." In the San Diego CATV matter relief was sought against previously authorized conduct, not against a violation, and the cease and desist order provision of the Act did not apply. If it had applied, the statutory procedure might have been mandatory. ${ }^{67}$ This procedural restriction on the Commission is of narrow and somewhat uncertain scope. It does not apply when regulations prescribe procedures for new functions not explicitly covered by the statute, as was true in the Southwestern Cable case itself. Even where a function, such as cease and desist orders, is subject to express statutory procedures, the Court has been willing to approve regulations authorized only in general terms and based on a different procedure, which displaced the statutory function and processes by settling a decisive issue in advance, as did the regulation proscribing certain kinds of natural gas price increase clauses in the Texaco case. ${ }^{68}$ It is far from certain, consequently, that the Court might not, where practical needs were met, approve a regulation that established a different procedure for performing a statutory function in toto.

Practicalities have supported the decisions of the federal courts in the growing number of recent cases, including Texaco, which have upheld the dis-

65. Id.

66. Id. at 179 .

67. The Federal Communications Commission proposes to use its cease and desist order authority, 47 U.S.C. $\$ 312$ (b) (1964), to enforce its rules applicable to CATV systems that do not use microwave and are therefore not dependent on licenses. CATV Second Report and Order, 2 F.C.C. 2d 725, 766 (1966). In this connection it presumably will follow the procedure prescribed in 47 U.S.C. \& $312(\mathrm{c})$ (1964). The cease and desist sanction applies to all violations of regulations and of license restrictions, as well as of the statute itself.

68. FPC v. Texaco, Inc., 377 U.S. 33 (1964). 
placement of agency adjudicative processes by rule-making authorized only by a general power to adopt regulations. In several instances the number of decisions to be made has required that certain issues be settled across the board rather than case by case, lest "the administrative heavens fall" and agencies be deprived "of ability to administer." Air Line Pilots Association, Intcrnational v. Quesada ${ }^{70}$ involved a regulation of the Civil Aeronautics Administrator establishing an age-limit of 60 for pilots operating commercial passenger planes. It in effect abridged the outstanding licenses of pilots, which under the Civil Aeronautics Act could be modified in individual instances only after opportunity for a full-scale hearing and judicial review. The court, in sustaining the regulation, pointed to procedural and substantive reasons why an agelimit rule served the statutory purpose of safety in aviation better than a series of adjudications to determine the continued fitness of individual pilots. In California Citizens Band Association v. United States ${ }^{71}$ a regulation altering the permissible uses of some 800,000 citizens-band radio licenses was sustained for similar reasons. In WBEN, Inc. v. United States, ${ }^{72}$ where the challenged regulations altered the range and effectiveness of the broadcasting of hundreds of commercial radio stations, the court applied the same reasoning; but in that case, as well, the Federal Communications Commission exercised a specific rule-making power to assign frequencies to classes of stations and regulate the manner of their use. ${ }^{73}$

The leading Supreme Court case on the foregoing point before Texaco, United States v. Storer Broadcasting Co., ${ }^{74}$ which sustained a regulation that limited the number of broadcasting stations a single licensee might own, did not involve a need to avoid many adjudicative proceedings. Neither did several recent court of appeals cases in the same series. ${ }^{75}$ In all these instances, however, the policy embodied in new regulations was "based upon the general characteristics of an industry"76 which could rationally and efficiently be appraised in an agency rule-making proceeding. As a result of this development the United States Court of Appeals for the District of Columbia was able to refer to the "solidly established tradition" of the Texaco and other cases.

69. WBEN, Inc. v. United States, 396 F.2d 601, 617 (2d Cir. 1968). (1961)

70. 276 F.2d 892 (1961). See also 286 F.2d 319 (2d Cir.), cert. denied, 366 U.S. 962

71. 375 F.2d 43 (9th Cir.), cert. denied, 389 U.S. 844 (1967).

72. 396 F.2d 601 (2d Cir. 1968).

73. 396 F.2d at 614 .

74. 351 U.S. 192 (1956).

75. American Airlines, Inc. v. CAB, 365 F.2d 939 (D.C. Cir. 1966) ; American Airlines, Inc. v. CAB, 359 F.2d 624 (D.C. Cir.), cert. denied, 385 U.S. 843 (1966) ; Capitol Airways, Inc. v. CAB, 292 F.2d 755 (D.C. Cir. 1961) ; Western Pacific R.R. v. Habermeyer, 382 F.2d 1003, 1006-07 (9th Cir. 1967), cert. denied, 390 U.S. 980 (1968) ("The receiving, processing and granting or denying of claims for benefits is wholesale business."). See also United Transports, Inc. v. United States, 245 F. Supp. 561 (W.D. Okla. 1965), aff'd, 383 U.S. 411 (1966); Motor Convoy, Inc. v. United States, 235 F. Supp. 250 (N.D. 'Ga. 1964), aff'd, 381 'U.S. 436 (1965). Compare Movers Conference of America v. United States, 205 F. Supp. 82 (S.D. Cal. 1962), with Movers Conference of America v. United States, 251 F. Supp. 882 (S.D. Cal. 1966).

76. WBEN, Inc. v. United States, 396 F.2d 601, (2d Cir. 1968). 
Under this "tradition" a general agency power to adopt regulations, which in an earlier view was generally regarded as authorizing only procedural and internal regulations, ${ }^{77}$ is now looked upon as empowering an agency to issue substantive rules having legal force against outsiders, even when the effect is to foreclose procedures otherwise secured by statute. ${ }^{78}$ Past zealousness to guard a licensee from having his license modified by rules when the statute required a hearing ${ }^{70}$ has only a lingering force. ${ }^{80}$

The provision of the Federal Administrative Procedure Act which affords interested persons an opportunity to submit to an agency data and views concerning proposed regulations ${ }^{81}$ encourages agencies to use, and courts to sustain, rule-making, even when the resulting regulations have a severe impact ${ }^{82}$ or supersede adjudicatory processes. The United States Court of Appeals for the District of Columbia has noted the change from pre-APA circumstances, ${ }^{83}$ and the Supreme Court ${ }^{84}$ and lower federal courts ${ }^{85}$ have stressed the adequacy of APA rule-making processes as a means of enabling affected persons to vindicate their interests. Also important in securing procedural fairness are the continued availability of processes to seek amendments to regulations ${ }^{86}$ or, under many agency rules of practice, exemptions from them in individual instances. ${ }^{87}$ Both these means of securing dispensation from distasteful regulations were present in the Storer Broadcasting ${ }^{88}$ and Texaco cases. ${ }^{89}$ It remains true, however, that all of these proceedings combined do not secure the same procedural rights as the forms of adjudication specified in the APA. Rule-making proceedings may be limited to written submissions; in them the

77. Lee, Legislative and Interpretative Regulations, 29 GEo. L.J. 1, 29 (1940).

78. Pacific Coast European Conference v. FMC, 376 F.2d 785, 789 (D.C. Cir. 1967).

79. Campbell v. Long \& Co., 281 U.S. 610 (1930) ; Campbell v. Galeno Chemical Co., 281 U.S. 599 (1930). See also L. B. Wilson, Inc. v. FCC, 170 F.2d 793 (D.C. Cir. 1948); FCC v. National Broadcasting Co. (KOA), 319 U.S. 239 (1943). Even in this view, the regulation remains valid with relation to licenses that issue after it takes effect. Goodwill Stations, Inc. v. FCC, 325 F.2d 637 (D.C. Cir. 1963); Transcontinent Television Corp. v. FCC, 308 F.2d 339 (D.C. Cir. 1962)

80. Cf. American Airlines, Inc. v. CAB, 359 F.2d 624, 634 (D.C. Cir. 1966) (en banc) (dissenting opinion), cert. denied, 385 U.S. 843 (1966).

81. 5 U.S.C. $\$ 553$ (Supp. III 1968).

82. American Trucking Ass'ns y. United States, 344 U.S. 298 (1953); Brooks Gas Corp. v. FPC, 383 F.2d 503 (D.C. Cir. 1967); Borden Co. v. Freeman, 256 F. Supp. 592 (D.N.J.), aff'd per curiam, 369 F.2d 404 (3d Cir. 1966), cert. denied, 386 U.S. 992 (1967); Air Dispatch, Inc. v. United States, 237 F. Supp. 450 (E.D. Pa. 1964), aff'd, 381 U.S. $412(1965)$.

83. Transcontinent Television Corp. v. FCC, 308 F.2d 339, 343 (D.C. Cir. 1962).

84. FPC v. Texaco, Inc., 377 U.S. 33, 40 (1964); United States v. Storer Broadcasting Co., 351 U.S. 192, 205 (1956).

85. WBEN, Inc. v. United States, 396 F.2d 601 (2d Cir. 1968) ; California Citizens Band Ass'n v. United States, 375 F.2d 43 (9th Cir. 1967); Air Line Pilots Ass'n, Int'1 v. Quesada, 276 F.2d 892 (2d Cir. 1960), cert. denied, 366 U.S. 962 (1961).

86. 5 U.S.C. \& 553(e) (Supp. III 1968) requires each agency to "give an interested person the right to petition for the issuance, amendment, or repeal of a rule."

87. The principal order in the Permian Basin Area Rate Cases and the CATV regulations of the FCC (see notes 44-63 supra and accompanying text) both preserved this opportunity.

88. United States v. Storer Broadcasting Co., 351 U.S. 192, 205 (1956).

89. See FPC v. Texaco, Inc., 377 U.S. 33, 40-41 (1964). 
attention of the agency is focused on a general problem and not on the situation of a particular party; persons to be affected may not have received notice of the proceeding or may acquire an interest in the matters involved only later ; $; 0$ and in a subsequent proceeding to amend $\mathrm{a}^{2}$ regulation or secure exemption from it a heavy burden of proof or of persuasion will rest upon the applicant. Representation by others similarly situated, rather than personal participation, becomes the means of safeguarding the interests of many of those affected.

There is little need for concern about such reductions in the procedural rights of interested persons as have been sanctioned to date by decisions sustaining the substitution of rule-making for adjudicative procedures. ${ }^{91}$ In each instance the court noted that the parties protesting the change had been participants in the rule-making proceeding that was used. When the number of potential adjudications was not so great as to threaten administrative paralysis if all were attempted, the issue which was determined by regulation was of a nature that made the rule-making procedure supportable. Three cases involving regulations of the Federal Maritime Commission are instructive. Two of them involved regulations of the Commission which required certain provisions in ocean shipping conference agreements. These cases related to membership conditions and dealings with shippers, ${ }^{02}$ as to which the relevant circumstances would hardly vary significantly from conference to conference. The earliest of the three cases dealt with regulations that outlawed certain kinds of dual-

90. See, e.g., The instance of nonappearance by the owners of certain small oil tankers in proceedings to establish regulations for the construction of such vessels, which is mentioned in REPT. Atr'y Gen's Comm. ON ADMIn. Proc. 114 (1941) ; Bigelow-Sanford Carpet Co. v. FTC, 294 F.2d 718 (D.C. Cir. 1961). Blake v. United States, 295 F.2d 91 (4th Cir. 1961), involved oyster growers who were held bound by regulations forbidding their markers in certain waters, which were adopted after proceedings that scemingly were not brought to the attention of these growers. Cf. Boyce Motor Lines, Inc. v. United States, 342 U.S. 337 (1952), in which the Supreme Court rejected a contention that a regulation of the Interstate Commerce Commission, applicable to the transportation of explosives by motor vehicles and enforceable by prosecution for violations, was impermissibly vague. The Court noted that "the trucking industry participated extensively" in the rule-making process. Id. at 341-42. It is doubtless true that participation by the truckers aided in making the regulation as definite as feasible; and the members of the industry could have pressed through trade associations or otherwise for its later modification. The Court did not state whether the particular trucker charged with a violation had taken part or been represented when the regulation was framed. There was no contention that the Commission did not have power to adopt rules governing the transportation of explosives or that any procedural rights had been withheld.

91. See, however, the contrary argument in FitzGerald, Adoption of Federal Powcr Commission Price-Changing Rules Without Evidentiary Hearing: Statutory Collision, 18 Sw. L.J. 236 (1964), with respect to the regulations later sustained by the Supreme Court in the Texaco case. Professor FitzGerald points out that as to these regulations no evidentiary hearings had been held either in the rule-making proceedings or in prior adjudications involving the same issues; that the regulations, without specific statutory authorization, dealt with important business and property rights; and that the lack of an administrative record curtailed judicial review. The rule-making and judicial review processes prescribed by the Administrative Procedure Act, 5 U.S.C. \& 551 et seq. (Supp. III 1968), require no more. Whether such processes are adequate remains a matter for judgment in each situation.

92. Outward Continental North Pac. Freight Conference v. FMC, 385 F.2d 981 (D.C. Cir. 1967) ; Pacific Coast European Conference v. FMC, 376 F.2d 785 (D.C. Cir. 1967). 
rate provisions in conference agreements. ${ }^{93}$ Since the effects of this type of provision on competition were the significant factors entering into Commission policy, and since these effects might arguably vary for different shipping routes and in relation to agreements of differing inclusiveness, a case could be made that a uniform rule was unsuitable and that each conference should have full procedural rights in connection with a determination that affected this aspect of its operations. The legislative history made it clear, however, that Congress intended to subject the matters involved in all three cases to determination by regulation in the discretion of the Commission. Hence the issues that were raised concerning the legal propriety of the use of rule-making did not seem serious. ${ }^{94}$ Even as respects the dual-rate regulation, approximately 60 different conference agreements were affected, and significant procedural economies were achieved by substituting a single proceeding for the separate ones that otherwise would have been required. ${ }^{95}$

Some kinds of questions are clearly susceptible to general determination by means of rule-making, without regard to participation in the proceedings by any particular affected persons. For example, the amount of residue of a poisonous chemical spray to be permitted on a food product sold for human consumption does not depend on who makes the chemical or sells the product. The special stake of chemical manufacturers and of food handlers in the issue is entirely subordinate and does not enable any of them to make a unique contribution to resolving it. By contrast, other kinds of determinations relate to situations that differ from each other in relevant ways. The general factors present are intertwined to such a degree with those dependent on each particular instance that judgments linking together each special situation with the general context in which it arises are required. For example, whether a corporate acquisition or merger may substantially lessen competition or tend to create a monopoly depends on the facts relating to the particular corporations involved and, at the same time, the circumstances existing in the industries and markets in which these corporations do business. If the statute makes no explicit provision for the use of general rules in this kind of determination but rather provides for adjudication in each instance, the legislative intention may well be that binding regulations to govern particular cases are not authorized. This would be true even though there is a general statutory provision permitting the agency to adopt regulations to carry out the act. The age-limit for pilots kind of question falls between the poisonous residue and corporate merger varieties of issues because the effects of age differ inherently from person to person, but scarcely to a degree which requires that, for the

93. Pacific Coast European Conference v. United States, 350 F.2d 197 (9th Cir. 1965).

94. The conferences pointed out, however, that loss of previous approval of conference agreements, not mere approval of new proposals, was involved.

95. 350 F.2d at 204. 
sake of realism and fairness, there be a determination in each case separately. ${ }^{00}$ As to each such issue, if the statute under which it arises does not make clear the procedures which may be employed, the agency and the reviewing courts must decide as realistically and fairly as they can whether rule-making is suitable.

The experience of the Federal Trade Commission with its recently established Trade Regulation Rules indicates the limits to an agency's use of general rule-making powers in place of adjudicative processes specified in statutes. The Commission has specific authority to issue legislative rules under certain relatively narrow statutes which it administers. ${ }^{97}$ The enforcement provisions of the broader statutes administered by the Commission, the Clayton and Federal Trade Commission Acts, specifically provide for enforcement only through the issuance of cease and desist orders based on trial-type adjudicatory hearings. Under the Clayton Act, the Commission's enforcement powers are to be exercised " $[\mathrm{w}]$ henever the Commission ... . shall have reason to believe that any person is violating or has violated" the provisions of the Act which are enforced by the Commission. ${ }^{98}$ In such a case "it shall issue . . a complaint stating its charges in that respect, and containing a notice of a hearing ...." Under the Federal Trade Commission Act the method of enforcement is the same, but it is enjoined upon the Commission only when it believes that a proceeding would be in the public interest. ${ }^{100}$ In addition the Commission under this Act is given authority "to make rules and regulations for the purpose of carrying out the provisions" of the Act. ${ }^{101}$

96. The problem here is not the same as determining the most appropriate procedure for resolving particular issues of fact. That problem can be stated in terms of whether a fact to be ascertained is "legislative" or "adjudicative"-i.e., general or related to a particular person or item of conduct. $1 \mathrm{~K}$. DAvis, AdMinistrative LAW TrEatise $\S 7.02$ (1958). The question then is which issues call for data and official notice and which for direct evidence. Such issues as the effects of age on ability to perform certain duties which an agency has authority to regulate are both general in nature and related to facts which differ from case to case. They are within the qualification to the statement that legislative facts "do not usually concern the immediate parties but are general facts which help the tribunal decide questions of law and policy and discretion." Id. at 413. When the fact to be determined, like that of the effects of age on pilots, not only concerns a party but may differ significantly in his case from the general norm (itself a conclusion drawn from particulars), he may have strong reasons to urge that he is entitled to an unprejudiced determination in his case separately, if the governing statute lends support to this view. The issue for agency and court in deciding on his contention is whether to make a norm decisive upon him (or at least difficult to overcome if exceptions to it are left open), or whether to assume the burden of separate adjudications in his case and all others like it. The resolution of this issue depends on considerations of administrative feasibility as much as on the nature of the fact or facts to be determined.

97. These statutes are enumerated in the Commission's Rules of Practice, 16 C.F.R. $\S \S 1.13,1.14$ (1968). They include the "quantity limit" provision of the Robinson-Patman Act, amending \& 2 of the Clayton Act, 15 U.S.C. \& 13(a) (1964).

98. 15 U.S.C. \& $21(\mathrm{~b})(1964)$. Enforcement of the most important provisions of the Clayton Act, $\S \S 2,3,7$ and 8,15 U.S.C. $\$ \S 13,14,18$ and 19 (1964), is entrusted to other agencies with respect to certain industries which these agencies regulate and to the Federal Trade Commission with respect to all other aspects of interstate and foreign commerce. 15 U.S. \& 21 (a) (1964).

99. 15 U.S.C. \& 21 (b) (1964).

100. 15 U.S.C. \& 45 (b) (1964).

101. 15 U.S.C. $\$ 46(\mathrm{~g})(1964)$. The Clayton Act does not confer a general rule- 
Under both principal acts the Federal Trade Commission made use from an early time of so-called Trade Practice Conference Rules (each of which covered a specific trade or industry and was formulated in conjunction with the group concerned) to aid in securing conformity to the statutes and to desirable business conduct. The rules consisted both of guides to the law and of statements of good trade practice. ${ }^{102}$ The rules containing statements as to lawful or unlawful practices were understood to be informative rather than legislative in character, but they purported to set forth legal requirements. ${ }^{103}$ In 1955 the Commission began to use other advisory pronouncements of a general nature, originally prepared as guides to staff members, ${ }^{104}$ which it could issue without prior proceedings or after such consultation or hearings as it might find desirable. ${ }^{105}$ These pronouncements became a significant element in efforts to secure widespread compliance with the statutes. ${ }^{106}$

In 1962 the Federal Trade Commission instituted a program for the use from time to time of Trade Regulation Rules which would possess a greater, but not clearly defined, legal force. ${ }^{107}$ The rule-making procedures prescribed by Section 4 of the Administrative Procedure Act were to be followed in preparing these Rules. ${ }^{108}$ An important instance of resort to Trade Regulation Rules was the formulation of regulations requiring the labeling and advertising

making power on the Commission, but it is probable that the power contained in the Federal Trade Commission Act, like the investigatory power similarly conferred, extends to the Commission's functions under the Clayton Act as well. See FTC v. Tuttle, 244 F.2d 605 (2d Cir.), cert. denied, 354 U.S. 925 (1957); FTC v. Reed, 243 F.2d 308 (7th Cir.), cert. denied, 355 U.S. 823 (1957); Menzies v. FTC, 242 F.2d 81 (4th Cir.), cert. denied, 353 U.S. 957 (1957).

102. See generally H. Select Comm. on Small Business, Antitrust Law Eivforcement bX the Federai Trade Commission and the Antirrust Division of the Departaient of Justice-A Preliminary Report, H.R. Rep. No. 3236, 81st Cong., 2d Sess. 30-34 (1951); Temporary National Economic Committee, 76th Cong., 3d Sess., Control of Unfarr Competitrue Practices Through Trade Practice Conference Procedure of the Federal Trade Commission 4-6 (Monograph No. 34, 1941); Handler, Unfair Competition, 21 Iowa L. Rev. 175, 253-255 (1936) ; Kittelle \& Mostow, A Review of the Trade Practice Conferences of the Federal Trade Commission; 8 Geo. WASrr. $L$. Rev. 427 (1940); Development in the Laz-Deceptive Advertising, 80 Harv. L. Rev. $1005,1088-1091$ (1967).

103. Sce Handler, sitpra note $102 ; 16$ C.F.R. \$ 17.3 (1968).

104. Baum \& Baker, Enforcement, Voluntary Compliance, and the Federal Trade Commission, 38 Ind. L.J. 322, 351 (1963) ; Auerbach, The Federal Trade Commission: Internal Organization and Procedure, 48 Minv. L. REv. 383, 452 (1954); Dissenting Statement of Commissioner Reilly in Devcon Corp., [1963-1965 Transfer Binder] TRADE REG. REP. $\mathbb{1 7}$ 1791, at 23,153 (FTC 1966). See Appendix B to cigarette advertising Trade Regulation Rule, 29 Fed. Reg. 8324, 8374 (1964).

105. 16 C.F.R. $\$ \$ 1.5,1.6$ (1968).

106. Baum \& Baker, supra note 104, at 351-353. Commissioner Elman contended at one point that they were as important and effective as more formally promulgated regulations and should require the same procedures before their issuance. See Dissenting Statement in Devcon Corp., [1963-1965 Transfer Binder] Trade Reg. Rep. If 17,791, at 23,150 (FTC 1966).

107. Baum \& Baker, supra note 104, at 353-55. The regulation of the Commission stating the effect of a Trade Regulation Rule provides that in adjudicative proceedings the Commission "may rely upon the rule" to resolve an issue to which it is relevant, "provided that the respondent shall have been given a fair hearing on the applicability of the rule to the particular case." 16 C.F.R. \$ 1.12 (c) (1968).

108. 16 C.F.R. \& 1.11 (1968). 
of cigarettes to give adequate warning of the health hazards of smoking. In an elaborate statement of the basis and purpose of such regulations, the Commission announced that the rules would be regarded in future complaint proceedings against alleged violators as having settled the matters they determined, leaving the respondent an opportunity to show that his conduct should be exempted. ${ }^{109}$ The validity and force of these regulations were not tested because they were superseded by an act of Congress which dealt directly with cigarette labeling and advertising. In enacting the statute Congress was careful to provide that nothing in it should "be construed ... to affirm or deny the Federal Trade Commission's holding that it has the authority to issue trade regulation rules."110

The Federal Trade Commission issued other Trade Regulation Rules covering deceptive practices under the Federal Trade Commission Act. ${ }^{111}$ After stating its intention to proceed similarly with regard to vertical mergers in the cement industry in relation to Section 7 of the Clayton Act, ${ }^{112}$ the Commission substituted an inquiry, including hearings, into relevant aspects of the industry in order to "help the Commission decide questions of law, policy, and discretion."113 Assa result, instead of Trade Regulation Rules, it issued a statement of "enforcement policy with respect to" such mergers. ${ }^{114}$ The statement specified conditions in local cement markets that would militate against the legality of vertical mergers in those markets and would cause complaints to be issued, but it noted at the same time "that the issues in any proceeding instituted by the Commission will be decided on the merits of that case."115

The Federal Trade Commission did not state whether Trade Regulation Rules might thereafter be undertaken with reference to other matters arising under the Clayton Act. The rules of practice of the Commission, which were subsequently revised, continued to provide broadly for Trade Regulation Rules to be issued after procedures identical to those for the legislative rules the Commission is empowered to make. ${ }^{116}$ In contrast, "Industry Guides" may be issued after informal proceedings or none at all. The answer to whether the Commission under its general rule-making power conferred by the Fed-

109. 29 Fed. Reg. 8324, 8371-73 (1964).

110. 15 U.S.C. \& 1334 (c) (Supp. III 1968).

111. See 16 C.F.R. ch. I, subch. D (1968).

112. 15 U.S.C. \& 18 (1964). See Permanente Cement Co., [1963-1965 Transfer Binder] TRADE REG. REP. T 16,885 (FTC 1964); Elman, Rulemaking Procedurcs in the FTC's Enforcement of the Merger Law, 78 HARv. L. Rev. 385 (1964). Elman, a member of the Federal Trade Commission, described the purpose of Trade Regulation Rule proceedings to be the provision of a framework of facts and standards, "within which the probable legality of prospective mergers could be measured quickly and with a fair degree of certainty." Id. at 390 .

113. 31 Fed. Reg. 6285, 7772 (1966).

114. Jan. 3, 1967, not published in the Federal Register, but included as an appendix to the report of Lehigh Portland Cement Co., [1965-67 Transfer Binder] TRADE REc. REP. I 17,845 (FTC 1967) (appendix at 1 TRAdE REG. REP. If 4510 (1968)).

115. Lehigh Portland Cement Co., [1965-67 Transfer Binder] Trade Reg. Rep. If 17,845 , at 23,209 (FTC 1967).

116. 16 C.F.R. $\S \S 1.15,1.16$ (1968). 
eral Trade Commission Act can issue regulations that will be binding in subsequent complaint proceedings, so as to exclude the issues they determine from later adjudicatory hearings, may differ as between that Act and the Clayton Act, or may vary under each act according to the subject matter. Variations in the language of the enforcement provisions of the two statutes probably are not significant. From a practical standpoint, the Federal Trade Commission Act embraces some matters, such as certain kinds of disclosure requirements in advertising, exemplified by the cigarette rules, which do not require variation of the Commission's action from case to case. Other matters, including many in the area of trade restraints and monopolistic practices, to which each statute or both together may apply, ${ }^{117}$ seem to require particularized judgments which the statute intends shall link together each situation presented and the general context in which it arises. The legality of a corporate acquisition or merger under Section 7 of the Clayton Act seems to belong in this latter category, as the Commission appears to have recognized.

The opinion in the Texaco case recognizes that the replacement of adjudication by rule-making pursuant to a general statutory authorization to issue regulations may not be valid with respect to some kinds of determinations. The Court noted that the regulations there involved "do not pass on the merits of any rate structure nor on the merits of a certificate of public convenience and necessity; they merely prescribe qualifications for applicants."118 This distinction is far from clear for the regulations dealt with the practices, not the qualifications, of applicants, and they did affect rates. A regulation which, on the basis of the usual rulemaking procedure, set a uniform rate of return to be applied in determining just and reasonable rates for natural gas, would raise a new kind of question.

In addition to the types of determinations to be made, the structure of the statute which is being applied and the consequences to affected persons of failure on their part to comply with particular agency requirements are important in determining whether regulations authorized only by a general rulemaking power may be used in laying down such requirements. In all of the

117. Sections 2,3 and 7 of the Clayton Act, 15 U.S.C. $\$ \$ 13,14,18$ (1964) prohibit price and other discrimination in the marketing of goods, exclusive dealing and tying arrangements, and corporate acquisitions or mergers, where (as to most of the practices covered) the effect may be substantially to lessen competition or tend to create a monopoly in any line of commerce. Section 5 of the Federal Trade Commission Act prohibits "unfair methods of competition" and "unfair or deceptive acts or practices" in interstate and foreign commerce. The first of these two clauses embraces trade restraints and monopolistic practices which threaten competition, as well as marketing methods which are injurious to competition. Were it not for the more specific provisions of the Clayton Act, many of the matters which that Act covers might have been found illegal under the Federal Trade Commission Act, as other anti-competitive practices have been. The Commission has employed $\$ 5$ of the Federal Trade Commission Act to prohibit practices closely related to those which $\$ 2$ of the Clayton Act renders illegal. American News Co. v. FTC, 300 F.2d 104 (2d Cir. 1962); Grand Union Co. v. FTC, 300 F.2d 92 (2d Cir. 1962). The necessity of judging business conduct in relation to its effects on competition consequently may arise under both statutes.

118. 377 U.S. at 42 . 
instances which have been reviewed, the consequences of inability or failure to satisfy a challenged regulation have been loss or failure to obtain a license or liability to issuance of a cease and desist order, backed by contempt process or penal sanctions. Violation of recently proposed regulations of the Food and Drug Administration dealing with sanitation in the manufacture of food products would, if the regulations became mandatory, subject the violator to criminal conviction for breach of the statute which the rules amplified. A different judicial interpretation or jury application of the statute would be foreclosed. The regulation would be authorized only by the power to "promulgate regulations for the efficient enforcement" of the Act. No means of enforcement for the regulations as such is provided. Other regulations, specifically authorized by the same statute, are enforceable by means which the statute specifies. In such a context, the use of regulations to spell out with binding effect the criminally enforceable statutory provisions would seem anomalous. ${ }^{110}$

Some of the CATV regulations of the Federal Communications Commission involved in the Southrvestern Cable decision strain the statute more than others. Microwave carriers that are licensed to transmit programs to CATV systems are required to take part in securing compliance with the regulations by the unlicensed systems they serve or wish to serve. Common carriers are required to serve only such systems as have filed with them written statements that specified notices of proposed operations have been given to broadcasters in the areas in which the systems will be located, and that the systems will abide by the regulations for local program carriage, exclusivity for such programs, and authorization by the Commission for bringing outside programs into any of the 100 largest television markets. ${ }^{120}$ Non-common carrier microwave enterprises must see to it that the CATV systems they serve comply with the same regulations. ${ }^{121}$ Disputes that may arise between broadcasters and CATV systems concerning compliance may be referred to the Commission by microwave common carriers as well as by the immediate parties, and the carrier is thereby relieved of obligation in the matter. ${ }^{122}$ These indirect means of enforcement are somewhat anomalous when considered against the background of a stafute which specifies direct sanctions to secure coinpliance by those whom it subjects specifically to the Commission's authority. ${ }^{123}$

119. Cf. Forte, The GMP Regulations and the Proper Scope of FDA Rule-Maluing Authority, 56 GEo. I.J. 688 (1968).

120. 47 C.F.R. $\$ \$ 21.712$ (a)-(i), $21.712(k), 21.714$ (1968).

121. 47 C.F.R $\$ \$ 91.559,91.561$ (1968).

122. 47 C.F.R. \& $21.712(j)(1968)$.

123. The statutory means of enforcement are license revocation and non-renewal, as weil as cease and desist orders against the licensee's failure "to operate substantially as set forth in a license" and against his continued violation of the regulations, 47 U.S.C. \& 312 (1964), together with criminal penaities, 47 U.S.C. \$ 502 (1964), and fines against broadcasters, 47 U.S.C. \& 503(b) (1964). Commission action sought by an applicant may of course be withheld on account of his noncompliance with a legal requirement. Common carriers are under a duty not to render service knowingly to customers who would use it to violate the criminal laws. Tracy v. Southern Bell Telephone Co., 37 F. Supp. 829 
The Commission regards the indirect scheme of enforcement as temporary, at least as respects common carriers, until it is satisfied that penal sanctions and cease and desist order processes, applicable directly to the CATV systems, will suffice. ${ }^{124}$

The CATV regulations as a whole are analogous substantively to the provisions of the Communications Act. The authorizations which systems in the 100 largest television markets must obtain if they desire to import programs are similar to the licensing of broadcasting stations, ${ }^{125}$ new common carrier wire service, ${ }^{126}$ and other users of the radio spectrum. ${ }^{127}$ The rules for the operation of CATV systems are not unlike the restrictions which broadcasters must observe, especially those relating to time sharing, program arrangements, and rebroadcasting. ${ }^{128}$ Procedurally the Commission's provision for non-record, informal processes in relief and disputes proceedings ${ }^{129}$ is an innovation in the statute, but need not operate differently from the informal methods which typically precede or dispense with record-type hearings. ${ }^{130}$ Formal processes follow when the Commission so determines. ${ }^{131}$

The moratorium on rate increases, contained in the Permian Basin order, similarly presents problems of adjustment to the statutory context: It substitutes its rule, mitigated only slightly by a tortuous means of relief, ${ }^{132}$ for the

(S.D. Fla. 1940) ; Hamilton v. Western Union Telegraph Co., 34 F. Supp. 928 (N.D. Ohio 1940). The Federal Communications Commission has, also, been sustained in refusing a certificate to a microwave operator for microwave transmissions to a CATV enterprise, the operation of which was found not to be in the public interest because it would have adverse competitive effects on broadcasters. Carter Mountain Transmission Corp. v. FCC, 321 F.2d 359 (D.C. Cir.), cert. denied, 375 U.S. 951 (1963). See also FPC v. Transcontinental Gas Pipe Line Co., 365 U.S. 1 (1961), and note 165 infra. By contrast, the affairs of even licensees themselves, which have no effect upon the aspects of the licensees' business that are subject to regulation, cannot be governed by the regulator. Regents of the University System of Georgia v. Carroll, 338 U.S. 586 (1950); cf. FCC v. American Broadcasting Co., 347 U.S. 284 (1954). The current CATV regulations deal, of course, with matters that do have an impact on the policies which were involved in the Carter Mountain case; but the use of licensees as a channel of control, not over their own affairs but over others', is a new way to carry out these policies.

124. CATV Second Report and Order, 2 F.C.C.2d 725, 766-67 (1966).

125. 47 U.S.C. $\$ \$ 307-11$ (1964).

126. 47 U.S.C. $\& 214$ (1964).

127. See note 123 supra; 47 C.F.R. Parts $21,23,74,89-99$ (1968).

128. 47 C.F.R. \&\$ 73.71-73.139, 73.281-73.300, 73.561-73.598, 73.651-73.679 (1968).

129. 47 C.F.R. \$\$ 21.712(j), 74.1109 (1968).

130. 5 U.S.C. $\S \S 55$ (c), 555(b) (Supp: III 1968).

131. 47 C.F.R. \& 74.1109 (1968).

132. This means of relief requires petitioning the Commission for higher rates. Action by the Commission would await the outcome of the proceeding thus begun. The Supreme Court declined to sanction the requirement imposed by the court below, Skelly Oil Co. v. FPC, 375 F.2d 6, 36 (10th Cir. 1967), that the Commission stay its principal order pending action on petitions for relief. 390 U.S. at 773-74. The Court referred to the Commission's discretion to modify or set aside an order in whole or in part under $\$ 19$ (a), (c) of the Natural Gas Act, 15 U.S.C. $\$ 717 \mathrm{r}(\mathrm{a})$, (c) as a possible means of avoiding undue hardship to producers. That authority continues, by the terms of the statute, until an order has become final or, after a timely petition for review has been filed, until the administrative record has been lodged in court. The Commission has authority to prescribe the date and the manner in which its orders shall become effective. 15 U.S.C. \$ 717o (1964). In the principal Permian Basin order it provided that "[n] otwithstanding the issuance of this final order, these proceedings shall remain open for such further action as may be necessary with respect to individual respondents and such other action as may 
individual adjudications upon rates which could otherwise have taken place under the statute. It seems reasonably justified if the across-the-board rates it was designed to protect were validly determined. To permit increases in those rates to be sought immediately by the normal statutory means might have precipitated a flood of applications that would in effect have reopened the whole vast proceeding. There was no reason to think that economic change affecting gas prices would be so rapid as to invalidate the results of that proceeding during the moratorium period. Yet individual producers were deprived of opportunities which the statute seemed to secure. It may be significant that the second area rate order, issued three years later, did not contain a similar provision. ${ }^{133}$

The proximate cause of potential hardship to some producers was, however, the fixation of uniform prices rather than the provision which kept these prices in effect for a relatively short period of time. The crucial question in the case was whether the determination of uniform prices based mainly on average-cost figures was a valid method of rate-fixing.

It could hardly be contended that the administrative determination of uniform prices for natural gas as a commodity, had it been directed by Congress, would not be a valid means of economic regulation. It would be valid even though individual sellers of gas might be forced out of business because their properly incurred costs were higher than the prices allowed, provided these prices were based on a rational gauging of relevent factors. ${ }^{134}$ This method was urged by Mr. Justice Jackson in the Hope Natural Gas case, which involved a pipeline. ${ }^{135}$ The majority of the Supreme Court, however, declined to apply it in that case. Instead they followed the view that the rates of a natural gas company, as of other utilities, should be so regulated as to meet the financial needs of the company, including an adequate return on investment. The Federal Power Commission, after the failure of its attempts to handle a large volume of single-company proceedings, applied the same principle to the large group of producers in the Permian Basin proceeding as a unit, as the Supreme Court in the intervening case of Wisconsin v. Federal

be necessary in the premises." II L, 34 F.P.C. at 243. It seems problematical whether this provision preserves a continuing power to modify the order, as distinguished from the power to supersede it by later final orders, including orders granting relief. $C f . \mathrm{CAB} v$. Delta Air Lines, Inc., 367 U.S. 316 (1961). In its opinion the Commission stated that the interim relief available to a petitioning producer would consist of permission to discontinue service temporarily, if the rate permitted by the order failed to meet out-of-pocket expenses. Id. at 180,227 . 1968).

133. Area Rate Proceeding, CCH UTIL. L. ReP. (2d ed.) II 10,983 at 13,611 (FPC

134. The Permian Basin opinion, citing earlier cases, asserts the validity of imposing maximum prices, or price ceilings, "upon commercial and other activities." In this connection "legislatures and administrative agencies may calculate rates for a regulated class without first evaluating the separate financial position of each member of the class . . . " 390 U.S. at 769.

135. FPC. v. Hope Natural Gas Co., 320 U.S. 591, 628 (1944) (separate opinion). 
Power Commission had indicated it might properly attempt to do. ${ }^{136}$ Costs vary enormously among gas producers because of differing experience in exploration, in the productivity of wells, and in the quality of gas discovered. Hence the profitability of uniform rates will also be spread over an extremely wide range, from large losses to rich rewards. To avoid such consequences, while remaining within the framework of pricing according to costs and without returning to the morass of individual-company pricing, would require that costs and rates be determined for subgroups of producers with similar experience. The Commission, however, used average costs of producing new gas in 1960, ascertained on a national basis, which it found to be sufficiently realistic for the area, and Permian Basin area-wide costs of gas from wells brought in earlier, ${ }^{137}$ in fixing rates for the entire group. Mr. Justice Douglas, dissenting, expressed strongly the view that an average-cost figure could not be sufficiently representative of actuality in widely varying individual instances. ${ }^{138}$ The majority, in mitigation of this and other deficiencies in the data, accepted the Commission's contention that future adjustments would suffice to achieve fuller compliance with the statutory standard of justness and reasonableness of rates. ${ }^{130}$ The Commission, in short, having by its order made significant progress toward satisfying the statute, is permitted to attempt to make further progress by refining its methods.

\section{Limits to Non-Legislative LegisLation}

The extensions of agency authority which the Supreme Court has sanctioned in the Permian Basin and Southwestern Cable decisions involve larger issues than those of adjustment to the statutory context and appropriateness of decisional method. These larger issues concern ways of shaping national policy in the utilization of new physical resources and advancing technology. They also involve basic questions of the relation of agencies and courts on the one hand and to the legislature on the other.

The allocation of natural gas, coal, and oil as energy sources for use now and in the future turns in part on the prices at which gas is allowed to be sold. The continued dominance of advertiser-supported, free-to-the-viewer television in the nation's homes may depend to a significant extent on protection from the intrusions of wired service. As to both matters, the controls initiated by both the agencies and the courts currently play a decisive role. They are at-

136. 373 U.S. 294, 309-10 (1963).

137. 390 U.S. at $761-64,799-803,815$. The Commission gave supplementary weight to noncost factors, such as the effects of prices on exploration and supply and the expectations of producers based on earlier policy statements of the Commission. Id. at 791, 795, 797, 799, 815. See Kitch, The Permian Basin Area Rate Cases and the Regulatory Determination of Price, 116 U. PA. L. REv. 191 (1967), commenting on the Commission's methods.

138. 390 U.S. at $829-37$.

139. 390 U.S. at $772,789,792,795,817,822$. 
tended by significant delays, uncertainties, and costs. Neither set of measures has as yet resulted in stability; the road of further experimentation by agencies and courts still lies ahead. Yet disruption and chaos in the two industries have been avoided and, at least, the felt needs and desires of consumers have been met at relatively low cost.

Whether the consequences of such measures are good in the long run cannot be determined adequately by their conformity to past legislative intention or by the degree of internal consistency in the resulting agency methods and policies. Legislative history played little role in the Philips Petroleum decision which brought about the regulation of independent natural gas producers' sales in interstate commerce. ${ }^{140}$ If the decision had been based on congressional intent, the result would have been the opposite of what it was, ${ }^{141}$ but not necessarily better for the country. As to CATV, which was unknown at the time the Communications Act was adopted, there could not have been a specific legislative intent. The Supreme Court's effort to demonstrate an actual congressional purpose to apply the Act to all future forms of radio and wire communication does not carry conviction. ${ }^{142}$ Again, however, the absence of a specific legislative intent to authorize the extension of agency authority does not prove that the decision sustaining the extension was wrong. Other criteria of statutory interpretation, which the Court also used, may support the decision. These include the literal meaning of the words of the statute, en-

140. Phillips Petroleum Co. v. Wisconsin, 347 U.S. 672 (1954).

141.: Cf. id. at 690-96 (Clark and Burton, JJ., dissenting). Excerpts from the legislative history appear in the opinion of the Court in FPC v. Panhandle Eastern Pipe Line Co., 337 U.S. 498, 509-13 (1949). There, however, the issue relating to Federal Power Commission authority over alienation of gas reserves previously owned by pipeline companies was quite different.

142. The Southwestern Cable opinion relies particularly on passages from the Senate committee report supporting passage of the Communications Act of 1934 and on words from a sentence in a message of President Roosevelt urging creation of the Communications Commission, which is quoted in the corresponding House report. 392 U.S. at 168 nn. 26-28; id. at 172. These statements advocate a "single Government agency" with "unified jurisdiction" and "broad authority" over "all forms of electrical communication." Read in the context of a proposal to combine in one agency the previous authority of the Radio Commission over the use of the radio spectrum and of the Interstate Commerce Commission over common carriers of communications by wire, and in the ahsence of specific references to the regulation of other existing or future forms of elcctrical communication, the statements do not lend support to an expansive interpretation of the Act. Neither the Commission nor the Court makes reference to the origin of $\S 303(r)$ of the Communications Act, the rule-making provision which is one of the two provisions principally relied upon as bestowing the means of implementing the Commission's "broad authority." This subsection was introduced into the Act in 1937 by legisiation to promote safety at sea, 50 Stat. 189, 191, 47 U.S.C. $\$ 303(\mathrm{I})$ (1964). It is highly unlikely that Congress intended at that tine to introduce into the Communications Act, without express recognition that it was doing so, a sweeping provision for carrying out broad powers previously given to the Commission. It is also of some significance that Congress in the original Act dealt specifically with a known instance of impact of wire services on broadcasting, instead of leaving it to be regulated under the broad authority which was later found in the statute. Section 202 (b), 48 Stat. 1070 (1934), provides for regnlation of charges and services "in connection with the use of common carrier wires in chain broadcasting" or in other radio communication. (Amended in 1960, 74 Stat. 888, 47 U.S.C. $\$ 202$ (b) (1964), to include common-carrier radio service, such as microwave, in the provision.) 
largement of statutory provisions to include situations analogous to those specifically covered, and extension of the statute to effectuate its purpose more fully.

There seems little doubt that the decisive factor in the Phillips Petroleum decision was the Supreme Court's belief, which later was made explicit, that the effectuation of the public interest which the Natural Gas Act was designed to protect required the establishment of the Federal Power Commission's authority to regulate sales in interstate commerce by independent gas producers. The Federal Communications Commission made the same kind of determination when it extended its authority to cover CATV systems. The difficulties and costs of the Natural Gas Act extension were not foreseen at the time, nor could possible alternatives outside the contours of the statute be fully explored in either instance. By the action that was taken, each agency was launched upon a program of innovation which, despite its boldness, remained of necessity within the established regulatory framework. Both the procedural and the substantive innovations to follow may depart further from established patterns, but are not likely to veer in entirely new directions. The Federal Power Commission, for example, can hardly set across-the-board just and reasonable natural gas rates entirely by means of rule-making without the participation of buyers and sellers who exercise the procedural rights of parties to adjudications. ${ }^{143}$ Neither is the Commission in a position to conclude, as Congress might, that it should approve all contract prices for gas which reflect arm'slength bargaining. ${ }^{144}$ Similarly, the Federal Communications Commission will hardly reverse its course by electing to entrust the public interest in lomereception television to competition between quasi-monopolistic local broadcasters, still restricted and protected in relation to each other, and locally franchised CATV enterprises ${ }^{145}$ which might possibly be required to pay fees to the originators of the programs they transmitted.148

143. Price- and wage-fixing for large numbers of enterprises is traditionally carried on in this fashion, but the Natural Gas Act provides too clearly for individual-company proceedings in the fixing of rates for these processes to be altogether displaced.

144. Whatever may now be said of the holding in City of Detroit v. FPC, 230 F.2d 810 (D.C. Cir.), cert. denied, 352 U.S. 829 (1956), that costs must remain the primary factor in determining the amount to be allowed to a pipeline company for natural gas it produces for itself, so as to serve the public interest in just and reasonable prices when the market might yield more, there is continuing validity to the principal point in the opinion, that the Commission must explicitly formulate a judgment that the specific prices allowed, not whatever the market may yield, will serve the primary aim of the Act: to guard the consumer against excessive rates. 230 F.2d at 815-19.

145. Franchising by local governments results from the necessity for permission to string CATV wires along public rights of way. It may have restrictive consequences for competition in the CATV aspect of television, similar to those which result on the broadcasting side from federal regulation.

146. The Federal Communications Commission has alluded to the unfairness of competition between broadcasters who must pay for local program rights and CATV services which not only invade their markets but do so without having to make similar payments. Rules re Microwave-Served CATV, 38 F.C.C. 683, 703-06 (1965); CATV Second Report and Order, 2 F.C.C.2d 725, 778-81 (1966). The Supreme Court has removed the possibility that, without legislation, payments might have to be made by 
Such radical changes of policy may, of course, be made by statute. Nothing that has been done by the agencies and courts has deprived Congress of its authority to legislate as it sees fit concerning these matters. The decisions and actions which have taken place can be viewed as measures of an essentially interim nature-the best that could be devised by those charged with responsibility, but subject to replacement whenever the legislature can prescribe better and more permanent solutions. The Federal Power Commission endorsed legislation to alter its mandate for several years after the Phillips Petroleum decision. ${ }^{147}$ The Federal Communications Commission, after vainly seeking legislative guidance, ${ }^{148}$ has expressed its concern not to give the appearance of foreclosing legislation by the actions it has feit called upon to take. ${ }^{149}$

Actualities in the continuing interplay between legislative measures and adininistrative and judicial actions complicate their relationships considerably, however. Legislative inertia and the difficulty of enacting statutes in the face of clashing interests are powerful forces. They support the status quo whether it be long established or newly created. Decisions not to extend regulatory power because of new developments tend to preserve non-regulation for indefinite periods. If an agency's existing powers are inadequate, it must then continue its work under the handicap of restricted ability to fulfill its purposes. Decisions to extend agency authority without new legislation, such as those under review here, create circumstances which, to a similar extent, are likely to continue. In addition, the interests that are benefited by a new administra-

CATV enterprises for their use of copyrighted material included in programs. Fortnightly Corp. v. United Artists Television, Inc., 392 U.S. 390 (1968). Seemingly it is still open to the Commission to require that CATV systems pay to the broadcasting stations or program originators, whose programs they use, reasonable sums for program rights, with or without a privilege in the sellers of these rights to withhold them altogether. Such a requirement without a privilege in the seller to withhold would involve great difficulties of determining suitable payments in individual instances, probably necessitating arbitration when agreement failed. If the privilege to withhold programs from CATV were given, program originators would be able to confer exclusive local rights on either broadcasting or CATV enterprises.

147. 35 FPC ANN. REP. 176-77 (1955); 36 FPC ANN. Rep. 19 (1956); 37 FPC ANN. REP. 25-26 (1957); 40 FPC ANN. REp. 17 (1960).

148. See United States v. Southwestern Cable Co., 392 U.S. 157, 164-65 (1968).

149. "In taking these actions, we have stressed our awareness that legislative action by the Congress in this area is both possible and desirable. We have moved to deal with the overall problem of CATV in a manner which we think will allow us to be most helpful to the Congress and at the same time give ts the maximum flexibility to act where action is needed." Rules re Microwave-Served CATV, 38 F.C.C. 683, 685 (1965). "We therefore state again that we would welcome congressional guidance as to policy and congressional clarification in all respects in this field." CATV Second Report and Order, 2 F.C.C.2d 725, 787 (1966). Iegislation of some sort is likely to take place in any event, if only to provide specifically for the copyright aspects of CATV relaying. Rapidly advancing technology, generating powerful conflicting interests, may require a new legislative start on the CATV problem as a whole, despite the Commission's best efforts. For summaries of recent and potential future developments, see Barnett \& Greenberg, A Proposal for Wired City Television, 1968 WASH. U.L.Q. 1 ; Cox, Competition In and Among the Broadcasting, CATV, and Pay-TV Industries, 13 ANTITrust BuLc. 911 (1968); Jones, Use and Regulation of the Radio Spectrum: Report on a Conference, 1968 WAsH. U.L.Q. 71 ; Proposed Rule Making, F.C.C., 33 Fed. Reg. 19028 (Dec. 20, 1968). 
tive or judicial development acquire added strength in subsequent legislative consideration of the problems involved. The principal bills to overcome the effects of Phillips Petroleum, for example, did not take the form of simple withdrawal of the authority newly bestowed on the Federal Power Commission. The next Congress, instead of focusing on such a measure, ${ }^{150}$ sought to prescribe different methods and policies for the Commission to follow. ${ }^{151}$ The bill which was passed by both houses but vetoed by President Eisenhower because of improprieties in the lobbying which accompanied its passage would have restricted the Commission to disallowing future excessive purchase prices of gas by pipeline companies in setting the rates these companies might charge. It would also have required that market factors, instead of producers' costs, be the basis of the prices fixed. ${ }^{152}$ The leading proposal in the next Congress would have retained direct control by the Commission over producers' subsequent prices, but have substituted market-price for cost-based price-fixing standards. ${ }^{153}$ Had any of these measures been enacted, the Supreme Court's Phillips decision would still have had permanent consequences which, without the decision, might never have arisen. ${ }^{154}$

The crucial long-term issue for agencies and courts when similar prob-

150. The struggle over regulation of independent producers' natural gas sales was one of the legislative "battles of the century." Before Phillips, the Kerr bill, passed by both houses but vetoed by President Truman, 96 CoNG. REc. 5304-05 (1950), would have excluded such sales specifically from regulation. Similar bills were introduced after Phillips, but were not reported out of committee, 35 FPC ANN. REP. 177-78 (1955).

151. 35 FPC ANN. REP. 177 (1955). Such proposals can be viewed either as a way of escape from effective regulation or as a means of more realistic regulation which could take account of some or all of the factors stressed by Mr. Justice Jackson in his Hope Natural Gas opinion, 320 U.S. 591, 628 (1944). See the House debate, 101 Cong. REC. 11855-930 (1955), and that in the Senate, 102 CoNG. REc. 1461-88, 1653-1716, 1949-2096 (1956).

152. 35 FPC ANn. Rep. 177 (1955). As to the veto see 102 Cong. Rec. 2897 (1956); H.R. Doc. 342, 84th Cong., 2d Sess. (1956).

153. The bill, H.R. 6790, is reproduced in Hearings on H.R. 6790, 6791 and Related Bills before the H. Comm. on Interstate Commerce, 85th Cong., 1st Sess. 8-11 (1957), and is summarized in 37 FPC A.NN. REP. 17-18 (1957), and ABA Mineral \& Natural Resources L. Section, Rep. Comm. on Natural Gas (1957 Proceedings) 75-77.

154. If it were inclined to do so, the Federal Power Commission could possibly, under its new freedom, apply the principles of the 1957 bill in exercising its present authority to prescribe just and reasonable rates, instead of continuing the area method. In the Permian Basin opinion the Supreme Court was at pains to state first, that the Commission is "free, within the limitations imposed by pertinent constitutional and statutory commands, to devise methods of regulation capable of equitably reconciling diverse and conflicting interests," 390 U.S. at 767; second, that in the Hope case the Court had "emphasized that we may not impose methods of regulation upon the discretion of the Commission," id. at 775; and third, that in FPC v. Natural Gas Pipeline Co., 315 U.S. 575, 586 (1942), the Court had "repudiated ... the suggestion that courts may properly require the Commission to employ any particular regulatory formula or coinbination of formulae," 390 U.S. at 775. Commissioner O'Connor, concurring except on a secondary point in the Permian Basin case, contended that the effect of the Commission's order was the same as would have resulted from avowedly making market prices, checked as to reasonableness by their consequences in eliciting supply and by "composite costs," the basis of decision; and he expressed the hope that this view "will become the rule." 34 F.P.C. at 243-44. Kitch, supra note 137, concludes that other factors than costs, coinciding conveniently with cost figures that had been modified significantly, were in fact decisive of the prices contained in the order. If the Supreme Court had taken this view, it would have had to decide whether rate-fixing based on these alternative factors was valid. 
lems arise is whether, in the light of probable consequences and a sound relationship of agencies and courts to the legislature, major extensions of regulatory authority should be undertaken without action by the legislature. The Permian Basin and Southwestern Cable decisions in this respect go beyond the most advanced principles of statutory construction that have been formulated. They exceed reasoning by analogy from situations previously covered, both because they launch new processes and because the economic reasoning on which they rest requires testing by considerations beyond the statute.

The conception Charles Curtis expressed with respect to statutory interpretation is of a discretion residing in those who apply a flexible statute, to adapt it to new circumstances instead of searching for the hidden intent of an extinct legislature. ${ }^{165}$ The scope of that discretion must be set by the competence of those who exercise it to weigh the relevant considerations and by the availability of means to effectuate the conclusions reached. Friedmann's suggestion that the limits of the extension of statutes by interpretation are reached when new "institutions" must be created" ${ }^{150}$ seems sound for many areas of law. When, however, an administrative agency is present to develop new institutions, including procedures and substantive regulations, the limits can be wider than when established methods of enforcement are the only ones available. Serving an ultimate statutory purpose may nevertheless require a choice among major alternatives which an agency, as well as a court, may not be capable of making. The methods an agency may adopt, moreover, can involve costs for both the agency ${ }^{157}$ and those subject to its authority, ${ }^{168}$ which

155. Curtis, $A$ Better Theory of Legal Interpretation, 3 VAND. L. REv. 407, 415

156. Friedmann, Legal Philosophy and Judicial Lawmaking, 61 CoLUn. L. REv. 821,839 (1961). When a court is the interpreter it must act without the "elaborate procedure of investigation and interpretation" which, as Henry M. Hart, Jr. has pointed out, a legislature has at its command in fashioning new law. LEGAL INSTITUTIONS TODAY AND Tonorrow, Comment at 40, 46 (M. Paulsen ed. 1959).

157. The agency's costs consist of those necessary to handle the matters coming before it. The Phillips Petroletem decision of 1954 imposed a totally new burden of independent producer certificate-application and rate cases on the Federal Power Commission, amounting in the first year to 6,047 applications and 10,978 rate filings. 35 FPC ANN. REP. 88, 108 (1955). A persistent fiscal year-end backlog of well over 2,000 independent-producer applications still pending, despite disposal of approximately an equal number during the year, remained from June 30,1956 (2,980 applications) to at least the same date in 1962 (2,355 applications). 36 FPC ANN. REP. 79-80 (1956); 42 FPC ANN. RxP. 104 (1962). The corresponding backlog of independent-producer rate cases rose from 274 to 2,939. 36 FPC ANN. Rxp. 85 (1956); 42 FPC ANN. RxP. 107 (1962). The backlog of applications had been reduced to 1,401 by June 30,1964 , but the rate cases awaiting disposition rose to 3,230. 44 FPC ANN. REP. 145-46 (1964). The correspending figures for June 30, 1966 were 917 and 3,216. 46 FPC ANN. RxP. 157, 159 (1966). New appropriations for the Commission did not differ significantly from those going to comparable agencies during the same years. The respective agencies' annual reports show the following:

\begin{tabular}{lcc}
\hline & 1956 & 1966 \\
\hline F.P.C. & $\$ 4,900,000$ & $\$ 13,530,000$ \\
F.C.C. & $7,323,000$ & $17,338,500$ \\
F.T.C. & $4,548,500$ & $13,671,000$ \\
\hline
\end{tabular}

* $\$ 145,939$ not used because of management improvements. 
call for scrutiny by the legislature. Disrepute of the administrative process and perhaps that of the courts, resulting from delays, uncertainties, and costs imposed by new burdens, may also be a consequence of extensions of authority when the extensions are not implemented by legislation. Such was the result, for a time, of the Phillips decision. ${ }^{159}$

The Supreme Court's developing doctrine of agency freedom to assume expanded authority when the attainment of statutory purposes seems to require it ${ }^{160}$ was enunciated in the Southwestern Cable case as a matter of deliberate choice. The Court ignored a narrower basis for the decision, which Mr. Justice White suggested in his concurring opinion. ${ }^{161}$ The reason for the Court's choice appears to lie in the belief that an expandable scope of authority, along with procedural flexibility, is necessary if regulation is to be effective under today's conditions. There is an obviously sound basis for this view. Rapidly changing economic and technological forces require resourcefulness and capacity for change at all levels of goverument if legal controls are to be effective. It is also true that, as Mr. Justice Douglas emphasized in his Phillips

FCC functions have expanded because of technological developments, notably television, and their increased use; those of the FTC have grown because legislation conferring new duties on the Commission and 2 heightened sense of the importance of effective regulation in its areas of concern. FPC expansion has been largely because of the addition to its jurisdiction brought about by the Phillips decision. Congress did not have an opportunity to consider whether it wished to authorize the consequent expenditures and future appropriations, as it does when statutes impose new duties.

158. The Court alluded in the Permian Basin opinion to the costs of regulation to natural gas producers, amounting in all to $1.164 \phi$ per thousand cubic feet of gas during 1956-58, 390 U.S. at 786-87 n.56, citing Gerwig, Natural Gas Production: A Study of Costs of Regulation, 5 J.L. \& EcoN. 69 (1962). This amount is between $5 \%$ and $10 \%$ of the great bulk of producer prices. Between $.039 \phi$ and $.078 \phi$ is attributable to the expense of participation in regulatory processes, and $.809 \phi$ to delay caused by those processes. Gerwig, id. at 86-87. The advent of firm area prices may diminish these costs substantially. The costs necessary to full participation in area rate proceedings, when these proceedings occur, have a different kind of impact which statistics do not reffect. See Mossburg, The Permian Decision-A Study in Group. Regulation, 19 OKLA. L. REv. 133 (1966). Expert services of economists and statisticians as well as of knowledgeable lawyers are required to deal, even by way of mere criticism, with the area-wide or nation-wide collections of data that are used. These services are beyond the means of any but the wealthiest participants or organizations of smaller participants. The proceedings therefore take on a representative character, contrasting with the processes traditionally available to individual litigants.

159. The Supreme Court in the Permian Basin opinion, 390 U.S. at 758, refers to Landis' comment, in his 1960 report on the regulatory agencies to President-elect Kennedy, on the Federal Power Commission's administration of the Natural Gas Act as the "outstanding example in the federal government of the breakdown of the administrative process."

160. See text accompanying notes 61-63 supra.

161. 392 U.S. at 181. The Communications Act provides in 47 U.S.C. $\$ 303(\mathrm{~h})$ (1964), that the Commission shall have authority "to establish areas or zones to be served by any [radio] station," and in 47 U.S.C. \$ 303(f) (1964), that it may issue regulations "to prevent interference between stations and to carry out the provisions" of the Act. It also provides in $\$ 301$ (47 U.S.C. $\$ 301$ (1964)) that the Commission may regulate "any apparatus for the transmission... of communications signals." Protection of the "areas or zones" of licensed television stations by means of the restrictions contained in the CATV regulations seems to come well within this authority. If there were doubt about the applicability of Commission regulations, authorized in this manner, to CATV wire systems, the extension of all the provisions of the Act to all wire communication, 47 U.S.C. 8152 (a) (1964), would seem to remove it. 
Petroleum dissent ${ }^{\mathbf{1 6 2}}$ and Commissioner Loevinger, dissenting, repeated in the Federal Communications Commission CATV proceeding, ${ }^{103}$ only the legislature is competent to undertake certain kinds of legal advances, including measures necessary to remedy deficiencies in existing statutes under some conditions. There is no escape from judging each situation as wisely as possible in the light of all relevant factors, including alternatives which do not lie on the surface of an established scheme of regulation, and of deciding on this basis whether or not an extension of agency authority should be undertaken without legislative participation. ${ }^{164}$

The necessity for such highly discretionary decisions, involving large consequences, creates opportunity for power-grabbing. There is no indication of a lust for power in the situations under review. ${ }^{105}$ Administrators and judges, seeking conscientiously to discharge their responsibilities, have sought to perform their duties effectively, subject to legislative authority, and have been resourceful in doing so. Error, not deliberate overreaching, is the more serious danger under these circumstances. If actual abuse at the administrative level should take place, it would probably be checked by judicial reversal or new legislation; and action by the legislature to overcome over-bold decisions by agencies or courts in the construction of statutes is available as well. When the merits of a particular agency or court determination are less clear, it is especially likely to endure despite doubts. If it involves major innovation, it is also likely to be a half-measure, compared to possible new legislation. Hence reluctance to expand authority greatly without legislative action, on the basis of vague statutory provisions, is wise.

162. 347 U.S. 672,690 :

Regulation of the business of producing and gathering natural gas involves considerations of which we know little and with which we are not competent to deal. 163. Rules re Microwave-Served CATV, 38 F.C.C. 683, 759, 760:

Undoubtedly the independent regulatory agencies have been given great power and broad discretion in its exercise. But if democratic government is to survive, the corollary ... must be a strong impulse of self-restraint in the exercise of such power.... If the laws are inadequate to cope with the problems of the moment, it is the function of Congress to remedy that lack.

164. Cf. M. Shapiro, The Supreare Court and Administrative Agencies 240-41, 244-49 (1968).

165. The conclusion in SHAPrRo, supra note 164 , as to the same factor in a related situation is to the contrary. Concededly the Federal Power Commission does not have direct jurisdiction over the end uses to which natural gas may be put or the prices at which gas in the ground may be sold to an ultimate user such as an industrial or electric power generating concern. A pipeline company wishing to transport gas interstate must, however, secure a certificate of convenience and necessity from the Commission. In FPC v. Transcontinental Gas Pipe Line Corp., 365 U.S. 1 (1961), the Supreme Court held that the Commission may take both factors into account, when relevant, in deciding upon the issuance of certificates. Shapiro ably analyzes the contending forces at work in this situation, including a desire of the Commission and supporting interests to stretch the Natural Gas Act beyond the bounds of an interpretation which the legislative history will support, and including also a policy-oriented judiciary which both abets and confines the agency by psychologically subtle responses. There is much truth in this picture even if, as this writer thinks, the Commission is less consistently bent on the enlargement of its authority than Shapiro seems to think and the opinion of the Supreme Court in the Transcontinental case is much more straightforward and sound in its conclusions than Shapiro apparently believes. 
Such a counsel of prudence does not eliminate the necessity of choice in difficult situations, but suggests that long-run consequences and alternatives be weighed with deference and great care. To some degree, significant extensions of agency authority, through the exercise of flexible powers, are inevitable under modern conditions. If not by the strikingly expansive decisions which have been the subject of this article, then by others of somewhat more limited scope, the charter of a new Administrative State needed to be fashioned. The one that has been written reduces administrative and judicial dependence on legislation far more than was traditional before, and sets highly elastic limits to authority. A prime task of administrative and judicial statesmanship in the future will be to judge wisely, situation by situation, where to draw the line between boldness and caution in exercising the power that now exists. 